\title{
In re Marriage of Stenquist: Tracing the Community Interest in Pension Rights Altered by Spousal Election
}

The supreme court held that rights in a disability pension are the separate property of the employee spouse only to the extent that they represent additional compensation over the alternative retirement pension riglits that would have been community property. This is a departure from the general rule that pensions characterized as "disability" pensions are separate property, and those characterized as "retirement" pensions are community property.

The conceptual distimction between disability and retirement benefits is grounded in the differing purposes and natures of the pensions. Retirement benefits, even if received after divorce, are considered community assets to the extent that they are earned as compensation for services rendered during coverture-they are essentially deferred compensation. ${ }^{2}$ In contrast, disability pay does not constitute deferred compensation for past.services, but ratler serves to compensate the disabled employee for his diminished capacity to earn im the future and for the personal anguish he suffers as a result of his imjuries. ${ }^{3}$

In Stenquist, the husband was a serviceman who was given the option of receiving either disability benefits (which were based in part on his rank and length of service) or his accrued right to retirement pay. The court refused to permit his election of the disability pension plan to defeat the community's interest $m$ his accrued retirement pension rights.

The court reached this result by applying alternative standards. First, the court allocated the disability pension to community property except to the extent that it was larger than the retirement benefits would have been. Thus, no matter whicl plan is chosen, tlie court will define a community property component that is equal to the value of the community interest im the retirement pension. Alternatively, the court set forth a standard of conduct-a spouse may not defeat the

1. 21 Cal. 3d 779, 582 P.2d 96, 148 Cal. Rptr. 9 (1978) (Tobriner, J.) (5-1 decision).

2. In re Marriage of Fithian, 10 Cal. 3d 592, 604, 517 P.2d 449, 456-57, 111 Cal. Rptr. 369, 376-77 (1974). (1975).

3. In re Marriage of Jones, 13 Cal. 3d 457, 459, 531 P.2d 420, 421, 119 Cal. Rptr. 108, 109 
community interest by electing between alternative pension rights. Even absent the court's definition of a community property coinponent ni any pension chosen, the court inade clear that a spouse would not be allowed to elect to benefit personally at the expense of the community.

This Note first argues that the court is actually setting forth one rule in the form of dual standards. Next, the Note explores the application of these standards in variant factual situations in an attempt to resolve a number of conceptual and valuational uncertainties left unanswered by Stenquist. Finally, the Note argues that the logic of Stenquist should be extended to inore complex election situations, such as those in which an einployee spouse elects to change jobs before pension rights vest.

I

\section{The OpINION}

\section{A. The Facts}

Lieutenant Colonel Stenquist enlisted in the Army in 1944 and nuarried Mrs. Stenquist in 1950. In 1953, he suffered a service-related injury that led to the ainputation of his left forearm. As a result of this accident, the Army assigned him a disability rating of eighty percent for pension calculation purposes. Although Stenquist could have retired then and received eighty percent of his then-current wage, he decided to remain on active duty. He retired in 1970, after serving twenty-six years in the Army.

A disabled serviceman may choose between two methods of determining his pension benefits. Under the first method, the servicennan's nuonthly basic pay at the time he ceases working is multiplied by the assigned percentage of disability. Under the second method, inonthly basic pay at retirement is multiplied by $2.5 \%$ times years of service. ${ }^{4}$ Thus, a disabled serviceinan may elect either to draw a disability pension or to accelerate the receipt of ordinary retirement pay, even if nonvested. Benefits received under either alternative are based in large part on rank and length of service, since monthly basic pay reflects these factors. In addition, regardless of the option chosen, the serviceman is limited to a maximuin monthly payinent of seventy-five percent of nionthly pay at retirement.

One nethod of calculation may be significantly more advantageous than the other, depending upon the length of time served and the extent of the disability. A career serviceman who suffers only partial disability may find that the retirement pay option yields a higher pen-

4. 10 U.S.C. $§ 1401$ (1976). 
sion than the disability option. The timing of the election may also affect the relative benefits under each option. If a serviceman is disabled early in his career and elects to retire at that time, the disability option inay prove superior. If, for example, Lt. Col. Stenquist had retired at the time of his injury in 1953, he would have received $75 \%$ of basic pay under the first alternative and only $22 \frac{1}{2} \%$ under the second. At the time of his retirement in 1970 he stood to receive the same $75 \%$ of his then-current basic pay under the first alternative (although his pay was considerably higher than it had been in 1953), but his benefits under the second had climbed to $65 \%$ of basic pay. Thus, a disabled serviceinan finds that the longer he serves, the more likely it will be that his straight retirement pay will equal or exceed his disability pay.

At the time of Lt. Col. Stenquist's retirement, the Army assumed that he desired the pension option that yielded the greater compensation, and therefore began making "disability" payments to him. Mr. Stenquist initiated divorce proceedings several years after he began receiving the disability pension. He contended that the entire disability pension should be his separate property. Mrs. Stenquist argued that the task of dividing pensions into separate and community property presented such a burden to trial courts that all "disabihty" pensions earned during coverture, as a general rule, should be deemed community property.

\section{B. The Law Before Stenquist}

In the past, courts made hittle attempt to allocate intangibles that were attributable to community effort, because it was felt that such assets were difficult or impossible to value. ${ }^{5}$ But since the value of retirement pensions is substantial and may, in many cases, be the major asset of the community, courts have sought recently to broaden the scope of the protection afforded the community imterest in pension rights.

For purposes of community-separate property allocation, pension benefits are classified under a two-step process. First, pension rights are classified as "vested" or "nonvested." Where pension rights are subject to forfeiture on the termination of the employment relationship, they are deenred nonvested. Conversely, pension rights are vested if they exist after the termination of the employment relationship. Pension rights are considered vested even though they may be subjcct to divestinent under extraordinary circumstances, such as a serviceman's being court-nartialed and dishonorably discharged, or for conditions unrelated to einployment, such as the employee's premature death. If

5. The judicial attempt to allocate the goodwill of a business upon divorce is one notable and anomalous exception. See Lurvey, Professional Goodwill on Marital Dissolution: Is It Property or Another Name for Alimony?, 52 CAL. ST. B.J. 27 (1977). 
the pension rights are found to be vested, the court must determine whether the vested rights have "matured." Pension rights are mature if the employee possesses a right to immediate payment.

The previously limited protection afforded the community interest in retirement pension rights stems from the California Supreme Court's 1941 decision in French v. French. ${ }^{6}$ The court held there that a Naval Reserve officer's retirement pay was not "property," but rather was a "mere expectancy"7 because the officer would not be entitled to retirement benefits until he had conipleted a fourteen-year term of service. Thus, unless the right to retirement benefits vested during the marriage, its value was not to be allocated between the parties. As the court recently observed, "the French rule ... rests on the theory that nonvested pension rights may be community, but . . . they are not property ....".

In In re Marriage of Jones, ${ }^{9}$ the court relied on the French rule in holding that a disabled Vietnam veteran who had been retired early for disability, and who thus acquired no vested right in a retirement pension, had only an expectancy imterest im a retirement pension; therefore, the disability payments he received were his separate property. Jones explicitly left open the question raised in Stenquist - whether a disability pension is a community asset when it is granted after the serviceman has earned a vested right to retirement pay. ${ }^{10}$

In 1976 the court in In re Marriage of Brown ${ }^{11}$ overturned the French rule that nonvested pension rights were not cominunity property. The Brown court held that a nonvested pension right was not a "mere expectancy," but rather was a contingent interest in property. ${ }^{12}$ The court characterized an "expectancy" as being the interest held by one who nierely foresees that he might receive a future benefit. For example, a beneficiary designated by a living insured who has the right to change beneficiaries has only an expectancy. By contrast, pension benefits were seen by the Brown court as deferred compensation, the right to which arose out of the employment contract, not the employer's beneficence. Such a contract right is not an expectancy, but is rather a chose in action, a form of property. ${ }^{13}$ Because nonvested pension rights

6. 17 Cal. $2 \mathrm{~d} 775,112$ P.2d 235 (1941).

7. Id. at 778,112 P.2d at 237. (1976).

8. In re Marriage of Brown, 15 Cal. 3d 838, 844, 544 P.2d 561, 564, 126 Cal. Rptr. 633, 636

9. 13 Cal. 3d 457, 531 P.2d 420, 119 Cal. Rptr. 108 (1975).

10. Id. at $461,531 \mathrm{P} .2 \mathrm{~d}$ at $423,119 \mathrm{Cal}$. Rptr. at 111 .

11. 15 Cal. 3d 838, 544 P.2d 561, 126 Cal. Rptr. 633 (1976).

12. Id. at 841,544 P.2d at 562,126 Cal. Rptr. at 634.

13. See, e.g., Hunter v. Sparling, 87 Cal. App. 2d 711, 197 P.2d 807 (1st Dist. 1948), where the contractual right to a pension was held enforceable under either the traditional principles of offer, acceptance and consideration, or the doctrine of promissory estoppel. Accord, Alder v. City 
constitute property, the court held that, notwithstanding problems of valuation, they were able to be allocated between the parties in the same inanner as vested pension rights.

\section{The Court's Analysis in Stenquist}

Stenquist was the first opportunity for the California Supreme Court to examine pension rights that could have been received as either retirement or disability benefits. Justice Tobriner's opinion upheld the trial court's characterization of the bulk of the "disability" pension as community property. ${ }^{14}$ The court first noted that, after Brown, the vested or nonvested nature of a pension right is no longer a factor in determining whether an interest in property is deemed community. Instead, the traditional test applies-does the right "derive from employinent during coverture"? ${ }^{15}$ Thus, the court held that the right of the husband to receive a disability pension could not be awarded as separate property to the extent that the benefits were earned during marriage because that would defeat the wife's presently valued community interest in the foregone retirement pension. ${ }^{16}$

Implicit in the opinion is the elementary property principle that once an interest is deeined to be jointly owned, decisions affecting such property must be inade in light of the interests of both owners. Applying this principle to the community property situation, the court concluded that one party unilaterally inay not make an election that prejudices the value of a community asset because to do so would "violate the settled principle that one spouse cannot, by invoking a condition wholly within his control, defeat the community interest of the other spouse." 17 The court did not invoke this principle to prevent the choice to receive a disability pension, since that would have prevented

of Pasadena, 57 Cal. 2d 609, 614, 371 P.2d 315, 317, 21 Cal. Rptr. 579, 581 (1962); Allen v. City of Long Beach, 45 Cal. 2d 128, 131, 287 P.2d 765, 767 (1955).

14. The trial court's calculations were as follows:

The ratio of that portion of the marriage from the commencement thereof up until the time of the petitioner's [husband's] retirement from military service, as compared with the entire total service of twenty-five years, eight months and ten days with which petitioner was credited, is seventy-seven percent (77\%). The Court therefore finds that had the petitioner retired on longevity retirement pay, the respondent [wife] would be entitled to $38.5 \%$ of such pay, as a division of commumity property, such percentage representing fifty percent (50\%) of the amount of such retirement accumulating during coverture. ...

[T]lhe Court finds that $65 / 75$ ths $(86.66 \%)$ of the disability retirement pay being received by the Petitioner would be community property to the extent the same was accrued during coverture, and that $77 \%$ thereof was so accrued during coverture, hence, $66.73 \%$ of said disability retirement pay is community property and one-half thereof $(33.36 \%$ rounded off to $331 / 3 \%$ for converience, by stipulation) is respondent's share.

21 Cal. 3d at 784 n.3, 582 P.2d at 99 n.3, 148 Cal. Rptr. at 12 n.3.

15. Id. at $785,582 \mathrm{P} .2 \mathrm{~d}$ at $100,148 \mathrm{Cal}$. Rptr. at 13.

16. Id.

17. Id. at $786,582 \mathrm{P} .2 \mathrm{~d}$ at $100,148 \mathrm{Cal}$. Rptr. at 13. 
Stenquist from choosing the inore valuable alternative. Instead, it forbade the unremedied "transmutation" of community property into separate property. ${ }^{18}$

The majority advanced a second reason for holding that a portion of this "disability" pension constituted community property. Havimg examined the government's scheme of benefits, the court concluded that there were few differences between "disability" and "retirement" benefits, and that one of the main functions of the military's disability pension scheme was to serve as a substitute for ordinary retirement pay. This conclusion was based on two rationales. First, the fact that a disabled serviceman must forego his retirement pay if he elects to receive disability benefits suggests that the disability pension has a builtin retirement component. Second, disability pay is computed in large part on the basis of length of service rather than solely on the extent of the disability, and therefore "serves the objective of providing support for the serviceman and his spouse after he leaves the service." 19 The court noted that as the veteran approaches normal retirement age, meeting his support needs inay become the predommant function served by the disability pension. ${ }^{20}$

The court found this to be so in the mstant case since "[t]he value of his [Stenquist's] present 'disability' pension depends largely on the high military rank he had achieved at the time of retirement and his extensive military service; it does not relate to his rank or longevity at the time of injury."21 Because of the extensive retirement support objectives of the disability pension and the fact that it supplanted a retirement pension, the court concluded that only that portion of disability pay that exceeds the value of the foregone retirement benefits serves the exclusive function of compensating the serviceman for his mjury. ${ }^{22}$ Therefore, only that portion can be considered separate property.

II

Two Standards For Determining the Separate or COMMUNity Status of PENSION Rights

The court created and apphed two standards in reaching its conclusion that a portion of the disability pension in Stenquist was a com-

18. Id.

19. Id. at $787,582 \mathrm{P} .2 \mathrm{~d}$ at $101,148 \mathrm{Cal}$. Rptr. at 14 .

20. Id.

21. Id.

22. Id. at 788, 582 P.2d at 101, 148 Cal. Rptr. at 14. For a detailed discussion of how an employee spouse's separate property right can become valueless by his continued employment, see note 24 infra. 
munity asset. The first standard serves a definitional function, and is based on the statutory presumption in favor of community property. Under this approach, if the einployer requires a disabled employee to choose between a retirement pension and a disability pension, the disability pension is defined as containing a retirement component equivalent to the value of the retirement pay foregone. The second standard is a measure of conduct: a spouse, by the exercise of a condition wholly within his control, may not impair the community imterest in order to increase his separate property. If a spouse elects against the community imterest, he will be precluded from furthering his separate property imterest at the community's expense.

\section{A. Definitional Standard: Presumption in Favor of Community Property}

To be deemed exclusively separate property, a pension must compensate for the disability and not serve as a substitute for retirement pay. In Stenquist, the court emphasized that the pension the husband received resembled a retirement pension more than a traditional disability pension because the employer calculated it mainly on the basis of length of service. The language of the opinion suggests that, to some extent, the court's forunula for differentiating disability from retirement pensions is based on an examination of the einployer's purpose-to provide retireinent support or to coinpensate the employee for his injuries-im providing the pension. But it is unlikely that this essentially subjective factor is determinative. The court did not examine the einployer's motivations or purposes in providing the disability pension. Rather, the court conclusively presumed that the employer, by the very act of forcing the employee to elect between pensions, was giving retirement pay im the guise of a disability pension. By means of this presumption, the court created a definitional standard for determining the extent of the corninunity interest. ${ }^{23}$ The test for determining the characterization of the pension is whether the choice of separate property in

23. This presumption is in keeping with the general statutory presumption in favor of community property: “[A]ll real property situated in this state and all personal property wherever situated acquired during the marriage by a married person while domiciled in this state . . . is community property . . . ." CAL. Crv. CoDE $\S 5110$ (West Supp. 1978). In the ordinary situation where the disputed property is purchased, the burden is upon the spouse asserting the separate character of the property to overcome the presumption that the property was acquired by community funds or effort. In re Marriage of Mix, 14 Cal. 3d 604, 536 P.2d 479, 122 Cal. Rptr. 79 (1975). Where the property right exists potentially in either form, however, the proof that the interest may exist in the forn of separate property cannot overcome the presumption in favor of community property, because proof of the property's separate nature would not negate the simultaneous existence of its community nature. Therefore, in order to be consonant with the community property presumption, an alternative forn of property interest, such as the pension rights here, must be deemed community if it may exist in community property form. 
fact supplants community property. To the extent that it does, the community interest will be restored by defining a community property component equal to the community property right supplanted. Thus, the court's formula provides for a simple restoration of benefits foregone. ${ }^{24}$

The court's discussion of the ease of applying the Stenquist holding at the trial level demonstrates that the "benefits foregone" formula is the sole criterion for measuring the community property component of a disability pension. The court characterized the process as "a simple mathematical computation based on the relationship of the "disability' pension to an alternative 'retirement' pension" 25 that would be easy to apply because it would not "involve any delicate balancing of the equities."26 Under this approach, courts avoid the hopeless and timeconsuming endeavor of attempting to inquire into the subjective motivations of each employer.

\section{B. Standard of Conduct: Spousal Election}

In addition to relying on the presumption im favor of community property, the court focused on the employee spouse's power to elect between pension options. By enunciating the "settled primciple that one spouse cannot, by invoking a condition wholly within his control, defeat the cominunity interest of the other spouse,"27 the court adopted

24. Under the "benefits foregone" formula, the disabled but still-employed serviceman may be faced with a dilemma if he considers the possibility of a future divorce. As a right to retirement pay accrues, the disabled spouse's separate property is reduced. By electing to retire early, before having earned a large retirement pension, the spouse can preserve a proportionately larger separate property component in the pension plan. But if, like Stenquist, he chooses to continue work$\mathrm{mg}$, his right to disability pay suffers at the expense of the community. Thus, timing may be an important consideration in the disabled spouse's decision to retire. The advantage of having a greater share of a less valuable pension must be balanced against the receipt of a smaller share of a larger pension.

25. 21 Cal. 3 d at 785 n.4, 582 P.2d at 99 n.4, 148 Cal. Rptr. at 12 n.4.

26. Id.

27. Id. at 786, 582 P.2d at 102, 148 Cal. Rptr. at 13 .

It is far from clear that this principle is "settled." It originated in the efforts of judges to avoid the all-or-nothing harshness of the pre-Brown vested or nonvested distinction and in response to problems of allocating the present value of a pension right that inight never mature (a difficulty the Brown court solved by providing for continuing jurisdiction). The principle has been einployed in two previous cases. In Waite v. Waite, 6 Cal. 3d 461, 492 P.2d 13, 99 Cal. Rptr. 325 (1972), the court used it to facilitate valuation, even though the pension might have been subject to suspension during the course of any temporary employment accepted by the retired spouse. Id. at 472, 492 P.2d at 20, 99 Cal. Rptr. at 332. And in In re Marriage of Peterson, 41 Cal. App. 3d 642, 115 Cal. Rptr. 184 (2d Dist. 1974), the court rejected the argument that the possibility of an employee spouse's continued employinent after his pension rights had matured prevents present valuation of those rights. The court reasoned that such an occurrence was a condition wholly within the spouse's control. Id. at 650-51,115 Cal. Rptr. at 190. The court in Peterson candidly acknowledged that both decisions were based on a similar "fiction" that contingencies wholly within the control of the employee spouse would not be allowed, for purposes of allocation on divorce, to 
a spousal standard of conduct as an alternative to the definitional standard. ${ }^{28}$

California courts previously had concluded that spouses stand in a fiduciary relationship to the community. The seminal case, Vai $v$. Bank of America, ${ }^{29}$ characterized the fiduciary responsibility of the spouse in control of an asset as both that of a truste $e^{30}$ and a business partner. ${ }^{31}$ Two factors, however, limit the usefulness of Vai in the pension election situation. First, the logic of Vai was predicated in part upon the then-existing statute that gave the husband full inanagerial control over the community property. ${ }^{32}$ Since that time, however, the California Civil Code has been amended to give either spouse the right to control community property and to introduce a duty to act in good faith with respect to the other spouse's interest in personal property. ${ }^{33}$ Second, the concept of a spousal fiduciary duty has been applied only to cases in which one spouse conceals, misrepresents, or inisinanages assets of the community; ${ }^{34}$ it has not been applied where one spouse openly asserts his separate riglit to certain assets. In this respect, the duty owed resenıbled niore closely the standard of good-faith dealing than it did a

affect the vested nature of a right that, but for the occurrence of the contingency, would be vested. Resort to such fictions after Brown was no longer necessary, and therefore the pre-Stenquist vitality of the principle is questionable.

28. For a discussion of the interstitial role of the spousal election standard, see text accoinpanying footnotes $45-46$ infra.

29. 56 Cal. 2d 329, 364 P.2d 247, 15 Cal. Rptr. 71 (1961).

30. Id. at 337, 364 P.2d at 251-52, 15 Cal. Rptr. at 75.

31. Id. at $339,364 \mathrm{P} .2 \mathrm{~d}$ at $253,15 \mathrm{Cal}$. Rptr. at 77 .

32. 1959 Cal. Stats., vol. 1 , ch. $125, \S 21$, at 2015 (current version at CAL. Crv. Code $\$ 5125$ (West Supp. 1978)). However, the husband's right of managerial control did not extend, at the time of $\mathrm{Vai}$, to any earnings generated by the wife before commingling. $1957 \mathrm{Cal}$. Stats., vol. 2, ch. 2334, \& 2, at 4066 (repealed 1973).

33. California Civil Code $\S 5125$ concerns management and control of personal property, and reads as follows:

a) [E]ither spouse has the manageinent and control of the community personal property, whether acquired prior to or on or after January 1, 1975, with like absolute power of disposition, other than testamentary, as the spouse has of the separate estate of the spouse.

e) Each spouse shall act in good faith with respect to the other spouse in the management and control of the community property.

CaL. CIV. Code $\S 5125$ (West Supp. 1978).

California Civil Code $\$ 5127$ concerns management and control of real property, and provides as follows: " $[E]$ ither spouse has the management and control of the community real property, whether acquired prior to or on or after January 1, 1975 . . . CAL. Civ. CoDe § 5127 (West Supp. 1978).

No court has ruled on the apphicability of $\S 5125(\mathrm{e})$ to pension benefits. For the possible interplay between $\S 5125$ (e) and the employee spouse's right to control the election of pension benefits, see text accoinpanying notes $39-40$ infra.

34. See, e.g., Fields v. Michael, 91 Cal. App. 2d 443, 205 P.2d 402 (2d Dist. 1949). For an argument that the fiduciary duty is cquivalent to a duty to deal in good faith, see Reppy, Community Property Reforms, 48 So. CAL. L. REv. 977, 1028 (1975). 
traditional fiduciary duty. Thus, in Boeseke v. Boeseke, ${ }^{35}$ the supreme court held that one spouse could protect his own interests during the process of division of property without violating his fiduciary duty, so long as there was no misrepresentation or concealment of material facts.

In re Mueller, ${ }^{36}$ to which the Stenquist court repeatedly referred, is the only case in which the election between alternative pensions is viewed in terms of fiduciary duty. In Mueller, the employee spouse, like Stenquist, was forced to choose between a disability or retirement pension. The court concluded that "[i]t would be inconsistent with the fiduciary duty owed by the spouse having management and control to permit that spouse to transmute what would otherwise be community property into his or her own separate property." ${ }^{37}$ The court in Stenquist, in quoting this language, omitted the language dealing with "fiduciary duty," and chose instead to use the words "community property principles"38 without further elaboration. The court may have deleted the reference to fiduciary duty because it wished to avoid adapting the logic of $V a i$ to the current statutory framework, but such an explanation does not seem convincing. Management of pension rights probably is not governed at all by new Civil Code section 5125, since the court held previously in Brown that the employee spouse should retain control over management of these rights on the theory that they are an integral part of the employment relationship. ${ }^{39}$ Consequently, the situation in which only one spouse exercises control over the asset is an ideal one for invoking some type of equitable duty toward the other spouse.

A more plausible explanation for the court's failure to use the language of fiduciary duty is that the court did not want to be constrained by the requirement of bad faith present in the fiduciary duty standard. The opinion defends, to a degree, the right of election: "The employee spouse retains the right to determine [by election] the nature of the benefits to be received." 40 Nonetheless, the election must not mcrease the

35. 10 Cal. 3d 844, 849, 519 P.2d 161, 164, 112 Cal. Rptr. 401, 404 (1974).

36. 70 Cal. App. 3d 66, 137 Cal. Rptr. 129 (4th Dist. 1977).

37. $\int d$. at $71-72,137$ Cal. Rptr. at 132.

38. The parallel sentence in Stenquist reads as follows: "It would be inconsistent with coinmunity property principles 'to permit that spouse to transmute what would otherwise be community property into his or her separate property.' " 21 Cal. 3d at 786, 582 P.2d at 100-01, 148 Cal. Rptr. at 13-14.

39. 15 Cal. 3d at 849-50, 544 P.2d at 568, 126 Cal. Rptr. at 640. See also Reppy, Community and Separate Interests in Pension and Social Security Benefits After Marriage of Brown and ERISA, 25 U.C.L.A. L. REv. 417, $426 \mathrm{n} .31$ (1978). Cf. the analogous right of sole control granted one spouse in managing a business. CAL. Crv. CoDE $\S 5125$ (d) (West Supp. 1978).

40. $21 \mathrm{Cal} .3 \mathrm{~d}$ at 786, $582 \mathrm{P} .2 \mathrm{~d}$ at 100, $148 \mathrm{Cal}$. Rptr. at 13. 
electing spouse's separate property at the expense of the community interest.

Thus, the court has established a duty broader than a fiduciary duty. Stenquist, by electing the higher disability pension, may have been acting in the highest good faith towards his wife im thinking that they would have a greater pension to share during retirement. But regardless of his good faith, lie was not allowed to transmute what would lave been community property into separate property. The duty is clear-if a spouse makes an election that impairs the community interest, he must not, as a result, increase his separate property at the expense of the community.

\section{III}

\section{Application to Other FaCt Situations}

As the factual contexts that follow illustrate, the allocation of pension rights under the Stenquist doctrine depends primarily on four variables:

(1) whether the pension rights are vested or nonvested;

(2) if the rights are vested, whether they have matured;

(3) whether or not the employee spouse is presented with a forced election between benefit plans; and

(4) whether the receipt of pension benefits was triggered by retirement or disability.

In Stenquist, both the right to retirement pay and the right to disability pay had matured and the spouse had retired by choice. Because there were no contingencies or conplicating factors, the result was apparent. However, this often may not be the case.

\section{A. Accelerated Right to Pension Benefits as Separate Property}

Suppose that, unlike Stenquist where both the right to retirement pay and the right to disability benefits were mature, the employee, as a result of a disability, chooses to quit working before his vested right to retirement pay inatures. This situation presents a conceptual problem. Applying the Stenquist mathematical fornula, one would calculate the extent of the disabled employee's separate property by deducting the unmatured right to retirement pay from the matured disability pension. In order to arrive at a proper result, however, only the present value of the unmatured right to retirement pay is deducted. ${ }^{41}$ Only then will the

41. The courts have never been faced with the situation in which there was a choice between a mature and a nonmature right, in part because nonvested rights were not valued before Brown, and in part because of the fortuity that no case arose that involved a choice between vested, but nonmature, and mature rights. 
dollar terms of these two rights be comparable. Yet applying the formula in such a inanner may not be desirable.

The difficulty in applying the Stenquist formula to forced election pension plans stems from the nature of the options available to the employee. The election triggered by a disability provides potentially greater compensation to the disabled employee in two ways. First and most obviously, the employee may choose a "disability" pension if it is higher than a "retirement" pension. Second, the military pension plan in Stenquist, like most forced election schemes, permits the disabled employee to receive immediately a pension that is calculated on the basis of his vested, though nonmature, right to retirement pay. Thus, the payments the employee receives before the retirement pension would have inatured are directly attributable to being disabled.

Even if the present disability pension payments could be characterized as containing a component attributable to vested, non-mature retirement benefits, the community's receipt of any part of such premature payinents cannot be justified under the definitional Stenquist standard. The accelerated right to retirement pay should be construed as a separate property right because it compensates for a disability; no present right to coinpensation that could be characterized as community yet exists. Under such an approach, pension benefits received by the employee-spouse would not be allocable to the community until the right to retirement benefits ordmarily would have become mature. ${ }^{42}$ Otherwise, the community would reap the benefit of a right it would not have were it not for the disability. ${ }^{43}$ Since no community interest is being supplanted, the characterization of the prematurely received benefits as community property is not justifiable. ${ }^{44}$

Nor can the community's present receipt of the accelerated payments be justified under the spousal election standard. If, through apphication of the definitional standard, the disability-triggered right to accelerated receipt of pension benefits is deemed a separate property right, recourse to the spousal election rationale cannot alter that property's separate nature; the property characterizations generated by the definitional standard are, by definition, incorporated into the spousal

42. In the case of a career serviceman, retirement benefits mature after 20 years of service. 10 U.S.C. § 1293 (1976).

43. Such a benefit could be of substantial value if the retirement occurred early in the serviceinan's career. For instance, if Stenquist retired in 1954 when $22 \frac{1}{2} \%$ of his pension was deemed community property, the right to receive that pension as his separate property in the interim until the retirement pay component ordinarily would have matured (here, 1964) would be substantial indeed. He would have received $111 / 4 \%$ of his base pay as separate property for 10 years.

44. In spite of this analysis, a court could conceivably investigate the nature of the original pension and conclude that the einployer intended to carry over to the accelerated benefits whatever retirement function the original pension performed. As discussed previously, however, a standard based on the employer's objectives is an unworkable one. 
election standard. Once an interest is determined to be separate property, the spousal election standard is inapplicable because there is no community property interest for the spouse to defeat. The spousal election standard serves only an interstitial role; it comes into play independently of the definitional standard only when the disability pension constitutes insufficient extant property to which the community label could attach ${ }^{45}$ or when the einployee spouse lias an incentive to defeat the community interest. ${ }^{46}$ Therefore, under both standards of the Stenquist opinion, accelerated benefits should be treated as the separate property of the disabled spouse.

The postponement of allocation until the right to retirement pay otherwise would have inatured would not place an undue burden on the courts. The court in Brown contemplated continumg jurisdiction as one ineans of obtaining an equitable division of pension rights. ${ }^{47}$ In practice, the postponeinent of allocation should lead at worst to only minor judicial inconvenience. At the dissolution proceedimgs, the judge normally only need order that, when the right to retirement pay would otherwise have matured, the pension payments must begin to be apportioned according to the Stenquist fornula. This would entail no inore effort than if the pension had been presently apportioncd, smce under either anethod the court would have to maintain jurisdiction to ensure that future paynents were equitably divided. Thus, a court should begin allocating the retirement component of the disability pension only upon the completion of all conditions necessary for maturation of the actual retirement pension. ${ }^{48}$

\section{B. Nonforfeiture of Nonvested Pension Rights}

Suppose now that, instead of the employee having a vested but nonmature right to retireinent pay, the retirement pension right is not even vested. The court in Stenquist implied that under post-Brown law,

45. Where for other reasons, such as tax consequences, the employee spouse chooses the disability pension even though it is smaller than the non-employee spouse's share of the retirement pension, there would be imsufficient extant property. For an example of the imterstitial application of the spousal election standard where there is insufficient extant property, see text accompanying notes 58-63 infra.

46. For an example of where there was an incentive to defeat the comununity interest, see text accompanying notes 49-60 and 80-81 infra.

47. 15 Cal. 3d at 849, 544 P.2d at 567-68, 126 Cal. Rptr. at 639-40.

48. The only condition that normally would be necessary for actual receipt of a retircment pension and that need not be met before judicial allocation of the rctirement component is the condition of being employed for the period required for the retirement pension to vest. To require that such a condition be met before defining a retirement component im the disability benefits would render all nonvested retirement pension rights valueless upon the employee spouse's clection to retire before the vesting of the retirement pension-a result contrary to the spousal election standard. For a discussion of the effect of a disability on the condition of contimued einployment necessary for retirement rights to vest, see text accompanying notes 49-60 infra. 
the community must be compensated for the foregone right to retirement pay, even though nonvested, on the theory that nonvested rights "constitute valuable community assets deserving of judicial protection" under Brown. ${ }^{49}$ Such a result, although correct from a policy standpoint, is not inandated by Stenquist. The "benefits foregone" formula does not require, by its own logic, the nonforfeiture of nonvested pension rights.

This conclusion may be demonstrated by an exammation of the different pension options an employer may offer and by application of the Stenquist formula to each. An employer is free to give both a retirement pension and a disability pension, one but not the other, or no pension at all. If the employer has no retirement pension system, but does offer a pension to tliose disabled on the job, then under the Stenquist definitional standard the entire pension could be characterized as separate property, even if it were calculated on the basis of length of service, because no retirement benefits would be foregone. ${ }^{50}$ A similar result would be appropriate if the employer sought to meet the retire-

49. 21 Cal. $3 d$ at 785,582 P.2d at 100,148 Cal. Rptr. at 13.

50. The question is still open whether the court would divide a disability pension that stands alone and is based on length of service into community and separate property components. Although it could be argued that the definitional standard of Stenquist should apply to situations in which there is no forced election but only one "disability" pension offered, and that the court should attempt to allocate to the community that portion of the disability pension that appears (because based on length of service) to constitute a retirement component, two reasons counsel against such a conclusion.

First, as discussed previously, the court's discussion of the simplicity of applying the formula suggests that, at least in the forced elcction situation, the court will not attcmpt to discern a retirement coinponent on the basis of the intentions of the employer, but will look only to whether a quantifiable rctirement pension was foreclosed. Indeed, the whole concept of a sirnple "benefits foregone" formula, i.e., that community property is preserved to the extent it would have been lost due to the employee spouse's election, is imconsisteut with an examination of subjective or unquantifiable factors. The court in Stenquist was careful to point out that the calculation of a pension right based on length of service is but one factor in determining the community status of property. The fact that ascertainable comnunity benefits are foregone is of at least equal importance: "Because it [the inihtary disability pension] replaces a "retirement" pension, and is computed in part on the basis of longevity of service and rank at retirement, it also serves the objective of providing support for the serviceman and his spouse after he leaves the service." $21 \mathrm{Cal}$. $3 \mathrm{~d}$ at 787, 582 P.2d at 101, 148 Cal. Rptr. at 14 (einphasis added). Furthermore, the court, in discussing why the disability pension in Stenquist contamed a community property component, noted that, "[t] he value of his [Stenquist's] present 'disability" pension depends largely on the high inilitary rank lie had achieved at the time of retirenent and his extensive inilitary service; it does not relate to his rank or longevity at the time of injury," id. (einphasis added), thus implymg that a disability pension based on length of service would be entirely separate property if it did not serve as the functional equivalent of retirement pay.

The court would be without guideposts if it were to attempt to calculate, without resorting to the Stenquist formula, what portion of a disability pension served a retirement pension function. If, under the Stenquist facts, there were no retirement pension available and Stenquist received $75 \%$ of his base pay, how would the court dctermme the retirement component? Would it split the pension equally between community and separate property? Would it take 40 years as the average length of a career and set the twenticth year as a watershed? Although such a pension inay, in 
ment needs of the employee by offering both a retirement and a disability pension imdependent of each other. Simce the rights would in no way be related, the court could not justify concludimg that the disability pension contamed a commumity property component, even if the payments were based in part upon length of service.

Where the employer gives the employee a choice of either disability benefits or his otherwise nonvested retirement benefits, finding a community interest becomes more complicated. The court's emphasis in Stenquist on the "benefits foregone" formula suggests that any pension right should be deemed separate property unless doing so would impair a realizable comınunity right. For the retiring employee who possesses only nonvested retirement pension rights, no realizable comnunity right would be impaired because the community can realize its interest in the retirement benefits only if they vest, and they never can do so once the employee retires.

The acceleration of vested rights discussed above provides a suitable analogy. In the acceleration situation, the early receipt of pension benefits can be attributed only to the disability. The value of the accelerated benefits, therefore, would be deemed separate property because, but for the disability that triggers the acceleration, there would be no present right to a pension. Applymg a "but for" analysis to the nonvested rights situation, we find that, but for the employer's offer of a disability pension regardless of whether the employee had any vested right to a retirement pension, the employee would have no pension rights, since the right to retirement pay would neither vest nor inature independently if the employee is unable or unwilling to contmue working. 51

The conclusion that nonvested rights have no value allocable to the community in the disability retirement situation is consistent with

theory, contain a retirement component of some degree, there is no way to measure it independently of the "benefits foregone" formula.

A second indication that the court would not attempt to allocate the components of a disability pension standing alone is its decision in In re Marriage of Jones, 13 Cal. 3d 457, 531 P.2d 420, 119 Cal. Rptr. 108 (1975). In Jones the disabled employee spouse had not served long enough to earn any vested retirement rights, but was awarded a substantial disability pension. At that time nonvested pension rights were not valued; consequently the disability pension was viewed as a solitary one, unaffected by any right to retirement pay. In that situation the court held the disability pension to be wholly separate property because it "compares to compensation for personal injury rather than to retireinent pay." Id. at 462, 531 P.2d at 424, 119 Cal. Rptr. at 112. Furthermore, this characterization of disability pay was cited with approval in Stenquist. 21 Cal. 3d at 787, 582 P.2d at 101, 148 Cal. Rptr. at 14. This suggests that a solitary disability pension without the right to elect an alternative retirement pension would be held to be separate property and that the logic of Stenguist should be limited to forced election situations.

51. Nonvested pension rights would not survive until maturity because nonvested rights are defined as rights which do not survive the termination of the employment relationship. In re Marriage of Brown, $15 \mathrm{Cal} .3 \mathrm{~d}$ at 842,544 P.2d at 563, $126 \mathrm{Cal}$. Rptr. at 635. 
the holding in Brown. There, the court was concerned with the inequity of not valuing a nonvested pension right that unore than likely would mature. But the remedies proposed in Brown suggest that the court did not view the community interest in any nonvested right as inviolate. The court recommended continuing jurisdiction in order that the risk that the pension might fail to vest would be divided equally between the spouses. ${ }^{52}$ This implies that if for any reason the pension failed to mature, the nonemployee spouse should receive nothing by way of the frustrated right. ${ }^{53}$ In the case of retirement due to disability, however, a court need not resort to the device of continuing jurisdiction to determine whether the community imterest will inature. It knows for certain that the interest will not mature because the einployee has retired. Thus, Brown stands for the proposition that the nonvested rights should be valued; it does not suggest that a nonvested right will always possess value.

As discussed above, where a retirennent pension and a disability pension both exist independently, the court would probably disregard a nonvested right to retirement pay and characterize a disability pension as entirely separate property. However, the court in Stenquist suggests that im a forced election situation a nonvested and a vested right to retirement pay would be treated equivalently ${ }^{54}$ - a disability pension would be defined as contaiming a community property component equal to the value of the foregone and nonvested retirement pension without reference to the fact that the retirement pension otherwise would not have vested.

The court's unique treatment of nonvested rights $\mathrm{m}$ the forced election situation seems influenced by two rationales. First, the fact that the pension in Stenquist looked so inuch like a retirement pension inay have lead the court to presume that the Army sought to give retireinent pay to the disabled. As discussed above, however, inquiry into the employer's motivations is an unworkable standard. The superior rationale from a policy standpoint is that this approach neutralizes any incentive a spouse nnay have to defeat the community interest. With the facts of Stenquist before it, the court was obviously concerned about the possibility that an employee with a right to a disability pension but still able to work would retire just before his retirement pension would vest, thus preventing the community rights from maturing.

52. Id. at 848,544 P.2d at 567,126 Cal. Rptr. at 639 .

53. Furthermore, there is no penalty for deciding to retire. The Stenquist court noted that if an einployee voluntarily chooses to retire before the right to a retirement pension vests, both the employee spouse and the community forfeit their rights to the foregone pension. The employee spouse owes nothing to the community despite the fact that rights were lost as the result of his actions. $21 \mathrm{Cal} .3 \mathrm{~d}$ at $788 \mathrm{n} .10,582$ P.2d at 102 n.10, 148 Cal. Rptr. at 15 n.10.

54. Id. at 788 n.9, 582 P.2d at 101 n.9, 148 Cal. Rptr. at 14 n.9. 
Although the disability pension would technically be separate property under a "but for" analysis, because no realizable community asset would have been lost, such a result would give the disabled spouse the incentive to defeat the community interest by giving him the ability to preserve community property rights in separate property form..$^{55}$ As one commentator has noted, ${ }^{56}$ "[t] $[$ he one theme that appears to tie the recent cases on all types of intangible property together is this concern that neither of the parties should be able to acquire an unfair share of the available assets through careful planning."

Since the problein of bad faith retirement would not be present in the case of a totally disabled employee who had no choice but to retire, the application of a strict "but for" analysis in that context is proper because there would be no possibility that the electing spouse could volitionally defeat the community interest. To apply this concept, the trial court would have to make the factual determmation of whether the disability is of a degree that would prevent contmued employment in the former position. If the court makes such a finding, it should deein the pension the disabled employee's separate property.

The fact that the court in Stenquist ${ }^{57}$ merely disapproved some of the language of Marriage of Jones ${ }^{58}$ without overruling it lends support to the theory that a "but for" analysis would be applied in this situation. In Jones the employee spouse was involuntarily retired and given a disability pension whiclı was held to be totally separate property; he had no opportunity to elect to contimue working. At the time of Jones the court had been looking for an opportunity to overturn the French rule that nonvested pension rights were mere expectancies, since its atteinpt in In re Marriage of Wilson ${ }^{59}$ had failed due to a faulty record. Yet it declined to overrule French when given the opportunity im Jones,

55. The incentive to defeat the community interest exists in the accelerated benefits situation as well. But in that context the incentive is unuch sunaller (being linited to only the interim payunents, see note 43 supra) and is probably more than offset by the benefits accruing to the employee spouse as the result of continuing einployment. Furthermore, in the retirement vesting situation, there is a definite time, relatively late in the employee's career, when a decision must be made or else the incentive will disappear (via the vesting of the retirement pension). When the employee is faced with this all-or-nothing decision, it is mueh more likely that he will elect against the community. In the acceleration situation, on the other hand, there is no similar decisional point because the benefit to be gained by electing agamst the coinmunity declines at a steady rate. Thus, in the retirement vesting situation, the coinbination of the decisional point and its occurrence at close to normal retirement age inakes the incentive to impair the community interest much greater than in the acceleration situation, where the major benefit can be gained only by retiring relatively early in the einployee's career.

56. Brandt, The Identification and Division of Intangible Community Property: Slicing the Invisible Pie, 6 U.C.D.L. REv. 26 (1973).

57. 21 Cal. 3d 779, 789 n.11, 582 P.2d 96, 102 n.11, 148 Cal. Rptr. 9, 15 n.11.

58. 13 Cal. 3d 457, 531 P.2d 420, 119 Cal. Rptr. 108 (1975).

59. 10 Cal. 3d 851, 519 P.2d 165, 112 Cal. Rptr. 405 (1974). 
and instead waited until the following year to do so in Marriage of Brown..$^{60}$ Perhaps the court was searching for a noneinployee spouse more sympathetic than the wife in Jones. Nevertheless, the fact that the court elected to wait until Marriage of Brown to overturn the French rule suggests that Jones may have continued validity. One plausible explanation of the result in Jones could be that because the employee spouse was totally disabled, he had no choice but to retire and was therefore not making an election against the community. Thus, there would be no mcentive for the spousal election standard to neutralize and the disability pension should be designated wholly separate property.

Assuming the court will follow its dictuin in Stenquist and treat nonvested and vested pension rights equivalently, such an approach would demonstrate the independent force of the spousal election standard of conduct. It may be invoked to remedy the more insidious "transmutations"- those where the definitional "but for" standard cannot neutralize successfully the employee spouse's incentive to prejudice the community interest. This approach will prove useful in analyzing employment election situations im Part IV.

\section{Election of Lower Pension}

Assuine a situation, such as the one in Stenquist, where both the right to disability benefits and the right to retirement pay are mature. The einployee is now faced with a forced election between these pension plans.

Under a retireinent plan like the one in Stenquist, a serviceman who retires after inany years of service is likely to find that his disability pension is no greater, and in fact inay be less, than his retireinent pension. Nevertheless, because a disability pension generally is exempt from taxation and a retirement pension is not, a disabled spouse inay find it $\mathrm{m}$ his interest to elect the disability pension even if its amount is substantially less.

It is clear from In re Marriage of Mueller ${ }^{61}$ that a spouse may not use tax savings as an excuse for avoiding application of the Stenquist formula. But an appellate court has yet to deal with the situation where a spouse elects the lesser of two pensions. Thus, the question remains, if a spouse elects a disability pension of sixty-five percent instead of a retirement pension of seventy-five percent, does the value of the nonemployee spouse's half of the community property consist of half of the foregone seventy-five percent pension or half of the sixty-

60. 15 Cal. 3d 838, 544 P.2d 561, 126 Cal. Rptr. 633 (1976).

61. 70 Cal. App. 3d 66, 137 Cal. Rptr. 129 (4th Dist. 1977). 
five percent pension? ${ }^{62}$ Viewed conceptually, is the Stenquist court's approach protective or corrective? Should the community label attach only to whatever pension assets exist after election up to the value of the foregone community asset? Or should the nonemployee spouse's interest in the foregone rights be preserved undiminished by the allocation of half the value of the foregone pension as his separate property?

The language in the Stenquist opimion could support either position. On the one hand, the court cited language from Mueller that "the amount received in lieu of matured retirement benefits remains community property subject to division on dissolution," 63 implying that perhaps the nommal anount of the community share is not fixed until after the election. On the other hand, the court emphasized that the decision in Stenquist is the result of the "protective philosophy of the community property law." 64 And in discussimg the spousal election standard, the court used language that seems to favor the preservation of the full value of the nonemployee spouse's interest in the origmal pension. In setting forth the duty of the employee spouse, the court stated that it would not "permit that spouse to transmute what would otherwise be community property into his or her separate property." This imphies that although the spouse has the right to elect between the pension plans, he inust restore the value of what otherwise would have been community property. ${ }^{66}$

The spousal standard of conduct is especially helpful for resolving those tax-influenced election situations in which the entire disability pension is smaller than the nonemployee spouse's share of the retireinent pension. While this problem may arise whenever an employee spouse is in a higher than fifty percent tax bracket, assume, for illustrative purposes, an employee spouse in the seventy percent tax bracket. He will have a tax mcentive to elect the disability pension if it is greater than thirty percent of the retirenient pension. If the amount of foregone community property to which the nonemployee spouse is entitled

62. It could be argued that this problem might be avoided by the nonemployee spouse also receiving the pension benefits tax-free, if the tax imcentives that make the lower pension more attractive to the employee spouse were equally beneficial to the nonemployee spouse. Even if the IRS allowed the tax-free nature of the disability pension to attach to the retirement component on divorce, however, often the nonemployee spouse would not be in as good a position as if he had received half of the foregone retirement pension because, after divorce, the nonemployee spouse nay be in a inuch lower tax bracket than the employee spouse.

63. $21 \mathrm{Cal} .3 \mathrm{~d}$ at 788,582 P.2d at $101,148 \mathrm{Cal}$. Rptr. at 14 (emphasis added).

64. Id. at 782, 582 P.2d at 98,148 Cal. Rptr. at 11 .

65. Id. at 786, 582 P.2d at 100-01, 148 Cal. Rptr. at 13-14.

66. This is consistent with the cases that affirm the allocation of individual assets unequally in order to arrive at the equal division of the community assets as a whole, as mandated by Civil Code \$ 4800. See In re Marriage of Brown, 15 Cal. 3d 838, 848 n.10, 544 P.2d 561, 567 n.10, 126 Cal. Rptr. 633, 639 n.10 (1976); Phillipson v. Bd. of Admin., 3 Cal. 3d 32, 46-47, 473 P.2d 765, 77475, 89 Cal. Rptr. 61, 70-71 (1970). See also Reppy, supra note 39, at 425 n.28. 
exceeds one hundred percent of the disability pension, that spouse's interest in the excess would not exist in pension property form. Thus, the standard of conduct approach is preferable in this context because its potential for reimburseinent of the community out of the electing spouse's separate property renoves the incentive and ability to impair the other spouse's interest, while at the same time allowing the employee spouse to take advantage of favorable tax consequences.

\section{Inequity Due to the Disabled Spouse's Forced Retirement}

One situation concerning the event that triggers the receipt of pension benefits remains to be examined. That is, does it matter whether the receipt of the pension benefits is due to the employee's decision to retire or to the forced termination of employment because of the disability? Fron the earlier discussion, ${ }^{67}$ it should be clear that in a forced election situation wlietlier the retirement pension rights are vested or nonvested will be of no consequence. Thus, the only real concern is whether the application of the Stenquist formula in this factual context will inequitably disadvantage the employee who is forced to retire because of his disability.

Justice Clark, dissenting in Stenquist, criticized the majority for placing disabled persons in a worse position than nondisabled individuals. Justice Clark's argument has no application under the facts of Stenquist, where the employee spouse's disability did not impair his ability to continue working and thus did not affect his retirement election. But where a spouse, confronted with a forced election scheme, is truly disabled and has no clioice but to retire, he is forced by application of the court's formula to pay a portion of his pension to his former spouse. In contrast, a lealthy spouse may choose not to retire until normal retirement age or later, thereby postponing, perhaps indefinitely, the receipt of any payments by the former spouse.

Under the Stenquist formula, the voluntarmess of the employee spouse's retirement does not affect the court's characterization of property. The court is concerned with the election between alternative retirenient plans rather than the election to retire. Whether or not the retirennent is involuntary, the disability pension will be deemed separate property only to the extent that it is greater than the retirement pension whicli it supplanted.

The court's failure to take into account the inability of the completely disabled to elect a later retirenient does not render Stenquist a flawed decision. To the extent that Justice Clark was arguing that the disabled are prevented from enjoying the financial rewards of contin-

67. See text accompanying notes 54-60 supra. 
ued employment, and thus are subject to a type of discrimination, he merely pointed out a discriminatory impact that is inherent in the fact of disability. But if Justice Clark was arguing that the disabled are not free to exploit the opportunity to continue working and thereby, at least temporarily, defeat the community interest, he was seeking to protect an election that, whether or not provable in a court of law, nevertheless is contrary to the duty to deal in good faith toward the interests of one's spouse.

Nor is the disabled spouse $\mathrm{n}$ as bad a position as Justice Clark suggested. First, as earlier noted, ${ }^{68}$ in the event of total disability a court should apply a strict "but for" analysis and refuse to deduct the value of nonvested rights from the disability pension (the policy reasons for neutralizing the incentive to defeat the community interest being absent, unlike in cases of slight or partial disability). Second, due to the separate property nature of accelerated pension benefits, no part of the disabled einployee's pension is allocable as community property until the right to retireinent pay has inatured. Thus, the disabled einployee would experience an adverse financial impact only upon the inaturation of a right vested at the time of disability. Third, as Justice Clark noted, if some imjustice results there is always the reparative option of spousal support. Spousal support in California is both sex-neutral and einployinent-neutral, ${ }^{69}$ and thus could flow from either spouse with equal ease. Indeed, the imitigating effect of the spousal support option would make especially inappropriate the characterization of property in a inanner not consonant with the presumptions set forth by community property law.

\section{IV}

\section{Application to EMPloyment Election Situations}

The Stenquist opinion focuses inainly on the application of the spousal election standard in what nay be termed simple election situations, that is, where the election is strictly volitional and accompanied by no other acts by the parties that would coinplicate property division. But the spousal election standard need not be limited to the simple election situation; it may be applied effectually in complex election situations as well, such as where an enployee spouse affects the community interest by electing to perforn some act such as changing jobs or working past normal retireinent age.

Courts traditionally lave shied away froin applying a spousal standard of conduct in conuplex pension election situations in part be-

68. See text accompanying notes 57-60 supra.

69. Cal. Civ. Code $\S 4801$ (West Supp. 1978). 
cause of the desire to avoid interfering with the einployer-employee relationship. In Brown, the court discussed this potential conflict:

As to the claim that our present holding will infringe upon the employee's freedom of contract, we note that judicial recognition of the nonemployee spouse's interest in vested pension rights has not limited the employee's freedom to change or terminate his employment, to agree to a modification of the terins of his employment (including retirement benefits), or to elect between alternative retirement programs. We do not conceive that judicial recognition of spousal rights in nonvested pensions will change the law im this respect. The employee retains the right to decide, and by his decision define, the nature of the retirement benefits owned by the community. ${ }^{70}$

It is clear, however, that such language refers only to the employee's actual freedoin to make an election; it does not extend to giving the employee control over the impact of his decision on the allocation of property to the community. The court in Brown, discussing Phillipson v. Board of Administration, ${ }^{71}$ indicated that the language of Brown should be limited to the actual freedom to make the election. In Phillipson, the employee spouse was ordered by the court to elect a particular pension plan. The Brown court distinguished this exception on the basis that the freedoin of election could be impaired because the trial court had allocated the entire pension to the nonemployed spouse in order to divide the assets equitably, and thus the employee spouse retained no beneficial interest in the pension rights.

Similarly, Stenquist implicitly recognizes the limited power of the employee spouse's election by noting that

[r]ecognition of the noneniployee spouse's interest in the 'disability' pension would not limit the employee's freedom 'to elect between alternative retirement programs.' . . . Any serviceman ehibible to receive 'disability' payments higher than ordinary retirement benefits would renain free to elect the higher payments if he so chose. ${ }^{72}$

The suggestion is clear that if the spouse elects the lower pension, the effect of his election will be subject to judicial inodification in order to protect the community interest. ${ }^{73}$ Thus, the Stenquist court's interpretation of Brown indicates that the language of Brown poses no impedi-

70. In re Marriage of Brown, 15 Cal. 3d 838, 849-50, 544 P.2d 561, 568, 126 Cal. Rptr. 633, 640 (citations omitted) (emphasis added).

71. 3 Cal. 3d 32, 473 P.2d 765, 89 Cal. Rptr. 61 (1970).

72. 21 Cal. $3 d$ at 786 n.6, 582 P.2d at 100 n.6, 148 Cal. Rptr. at 13 n.6.

73. Although it could be inferred from this language that the court might not allow the employee spouse to elect the lower of the two pensions, it would be preferable to allow the election and then require discharge of the duty of rembursement (as long as there is sufficient separate property for reimbursement of the community) as was recommended in the tax election situation. See text accompanying notes 61-66 supra. 
ment to an application of the spousal election standard to complex election situations, if warranted.

As is apparent from the court's treatment of nonvested pension rights im the forced election situation, the removal of the imcentive for the employee spouse to impair the interests of the community is an important goal of community property law. In more common employment decisions involving no disability, the incentive for an employee spouse to defeat the community interest should not only be eliminated for the sake of the community, it should also be neutralized so that economic decisions are made solely on their own merit and are not colored by what would be, in effect, subsidies received at the expense of the community. Consequently, with an eye to both these factors, this Note next will examme three of the inost common employment election situations-early or preinature retirement, delayed or post-mature retireinent, and the election to change employment.

\section{A. Premature Retirement}

The case in which an einployee elects to retire before he has accrued any vested pension rights is the easiest of the three situations to analyze. Assuming we are not dealing with a disability situation, the pension rights would simply vanish upon premature retirement. Thus, the inability of the employee spouse to realize the benefit of such rights in any form ${ }^{74}$ eliminates the incentive to act agamst the community's interest. So long as the employee spouse's and the community's interests are identical, the community's interest will not be prejudiced, and therefore there is no reason to apply the logic of Stenquist.

Furthermore, the result of forcing the employee to compensate the spouse for a right never received is far different from dividing a right that lias been realized. In the former situation, the separate property of one spouse is being shifted inequitably to the other, not on the basis of need, as in the spousal support situation, but as a matter of right. Such a transfer of property already determined to be separate, except in the unusual circumstance in which it is necessary to neutralize an imcentive to defeat the community interest, is improper and contrary to the community property-separate property dichotomy upon which the community property regime is premised. Thus, the premature retirement situation does not warrant application of the Stenquist formula.

74. It could be argued that the employee spouse is being paid in increased leisure time, but this factor should be disregarded in community property calculations, just as it is in the computation of taxable income. 


\section{B. Post-Mature Retirement}

The logic of Stenquist does apply to the situation in which, following dissolution, the employee spouse continues to work after retirement pension rights mature. One commentator ${ }^{75}$ concluded that it would be improper, on the basis of the principles of spousal risk-sharing and freedom of contract set forth in Brown, for the nonemployee spouse to receive his or her share of a pension before the einployee spouse actually received a pension payment from the employer. Such a conclusion is based on two rationales. First, if for any reason, such as death or discharge for cause, the pension is divested, the risk of divestment would not have been shared equally. Second, until the employee spouse receives pension payments he must compensate his spouse with his own separate property and is therefore "penalized" for not retiring.

While at first glance this appears to be the case, the conclusion is based on a fundamental misconception as to what constitutes separate property under the logic of Stenquist. Viewed from an economist's perspective, the employee spouse's compensation for continued employment is not the full amount of his paycheck. Rather, his compensation is only that amount above the pension benefits that he will not receive while he contimues working. For example, in the matured pension situation, if the employee can receive retirement pay in the amount of $X$ dollars without working, then his actual compensation for services rendered is not the amount of his paycheck, $\mathrm{Y}$ dollars, but $\mathrm{Y}$ minus $\mathrm{X}$ dollars. This is nothing more than a reapplication of the "benefits foregone" fornula of Stenquist. ${ }^{76}$ Therefore, rather than penalizing the spouse for not retiring, the contrary is true-the community is being penalized because it is forced to subsidize the employee spouse's salary, which becomes his separate property.

Nor does the possibility of divestment of the pension rights render this method of allocation inequitable. Assuming that the employee's earnings contaim a community property component under the above analysis, the nonemployee spouse cannot be overcompensated so long as the benefits are allocated on a monthly basis under continuing jurisdiction. ${ }^{77}$ Thus, if an employee spouse dies three months after the pen-

75. Stratton, Dividing the Community Property Interest in Nonvested Pension Rights, 65 CALIF. L. Rev. 275 (1977).

76. Although the election of the disability pension, if uncorrected, would lead to the total defeat of the community interest, whereas post-mature retirement merely postpones it, the two situations are parallel. Postponement, especially late in life, is often the equivalent of complete defeat. Not only are the employee spouse's chances of dying on the job increasing with each passing year (in which case the pension rights would vanish under most plans), the present value of money is much nore valuable as a person enters the last years of his life.

77. To ensure that the employee spouse is prompt in making his inonthly payments, the court should reserve the option of dividing the present value of the pension rights. The threat of 
sion rights mature, only the value of three monthly pension payments would be apportioned-exactly the value of the commumity imterest under the above analysis. Indeed, any other result would inequitably limit the community's receipt of property.

Although the Stenquist court suggested in a footnote that it considered the postponement of retirement to have the effect of forfeiting the right to retirement pay during the period of contimued employment, ${ }^{78}$ such an approach is inconsistent with the logic of the decision. And the two cases cited by the court as authority for the spousal election standard both invoked the standard against an employee spouse who attempted to claim that there should be no present allocation of pension rights because he might not retire. ${ }^{79}$

Furthermore, the present allocation of the mature retirement pension would go a long way towards overcoming the dissent's charge of discrimination against the disabled. Justice Clark's criticism is not predicated on concepts of fundamental equity. Instead, the complaint is that disabled persons are discriminated against because they cannot take advantage of the post-mature retirement loophole. Rather than distinguishing the cases of a healthy and a disabled employee, it would be conceptually preferable, as well as practically inore equitable, to allow no loophole in the first place.

\section{Change of Employment}

The situation in which the employee spouse elects to change jobs before the community right to a retirement pension vests is analogous to that in which the disabled einployee elects to retire and receive disability benefits, thereby defeating the community right to a retirement pension. ${ }^{80}$ In both cases the logic of the definitional standard does not require an allocation to the community. The spousal election standard, however, comes into play when an incentive to defeat the community interest is present. Under present law, when a divorced employee

having to make a lump sum payment of the total present value of the pension would assure compliance with the monthly payment scheme.

78. $21 \mathrm{Cal} .3 \mathrm{~d}$ at $788 \mathrm{n} .10,582 \mathrm{P} .2 \mathrm{~d}$ at $102 \mathrm{n} .10,148 \mathrm{Cal}$. Rptr. at $15 \mathrm{n} .10$.

79. In Waite v. Waite, $6 \mathrm{Cal} .3 \mathrm{~d} 461,492$ P.2d 13, 99 Cal. Rptr. 325 (1972), the possibility that a retired judge would accept temporary judicial assignments that would suspend any pension for the duration of the employment was insufficient to prevent present allocation. Similarly, im $I n$ re Marriage of Peterson, 41 Cal. App. 3d 642, 115 Cal. Rptr. 184 (2d Dist. 1974), the employee was not allowed to assert that he had no plans to retire upon reaching retirement age. These courts did not have the option of continuing jurisdiction set forth in Brown, and therefore had to allocate the pension rights at the time of divorce regardless of future contingencies. Given the inequity of the post-mature retirement situation, a similar policy consideration (i.e., preservation of the commumity interest in the face of an unfriendly election of continued employment) should lead to a similar application of the standard.

80. See text accompanying notes 49-60 supra. 
leaves a job at which his pension rights are nonvested and transfers to a second job, any right the community may have had in the pension rights would be forfeited because of their nonvested status. This ability to alter the property label attaching to pension rights presents the divorced employee spouse with a significant imcentive to change jobs.

The previous discussion of the premature retirement situation demonstrates that the employee spouse could defeat the community's interest by retiring before the pension rights vest. There, however, it was argued that the spousal election standard should not be applied because no incentive to defeat the interest exists. That is, by retiring early and thereby forfeiting the nonvested right to pension benefits, the employee spouse does not advance his separate property at the expense of the community. No one receives any pension benefits.

In the change of employment context, on the other hand, the application of the spousal election standard is warranted. To the extent that the compensation generated by the second job is greater than the employee spouse's salary would have been had he reinained at the first job, the employee spouse, by changing employment, has preserved the value of the community pension rights, but in separate property form. The spousal election standard should be invoked under these circumstances because some portion of the value of the pension, although no portion of the right, is preserved and this preservation of value constitutes a possible incentive to elect against the community imterest. This situation is analogous to the nonforfeiture of nonvested rights in the simple election of a disability pension over a nonvested retireinent pension. The definitional standard will provide no practical protection for the community; once the employee spouse quits his first job his pension rights will never vest and therefore will never have value. Instead, the protection of the community interest is limited to the neutralization of the incentive to transmute community property into separate property. Thus, to the extent the value of the foregone retirement pension rights is preserved, it should be allocated as a community asset.

Although compensation theoretically can exist in both quantifiable and nonquantifiable forms, ${ }^{81}$ the application of the spousal election standard need neutralize only that imcentive presented by quantifiable compensation. Not only is nonquantifiable coinpensation relatively unimportant in most employment election decisions in comparison to quantifiable compensation, but its nonquantifiable nature also makes it inappropriate for judicial consideration or allocation.

81. In the change of employment situation, an employee may receive both economic and noneconomic compensation. Compensation can exist in quantifiable form such as salary, pension benefits, or other perquisites capable of dollar valuation, or it can exist in nonquantifiable form such as quahty of the working environment. 
Three examples will serve to illustrate the proper application of the spousal election standard to change of employment situations. First, if the quantifiable compensation (mcluding pension benefits) at the second employment exceeds or is equal to that of the first, the value of the pension benefits has been preserved and the noneinployee spouse should be paid the portion of the pension benefits that he would have received liad the einployee spouse not changed einployinent. If, on the other hand, the total coinpensation from the second einployment is less than the compensation from the first, excluding the pension interest, then the spousal election standard would be inapplicable because there would be no preservation of the value of the pension benefits in any form. Finally, if the situation is one which falls in the gray area where the compensation is neither insufficient nor wholly sufficient to render a full award of benefits to the community, there should be a proration. Thus, to the extent that the total coinpensation from the second job exceeds the non-pension compensation froin the first, any surplus slould be divided as a community asset.

To the extent that the second job provides a pension right of suffcient value to replace the foregone pension, it should be treated as a substitute right. But if the compensation from the second einployment affords imsufficient pension benefits or is solely in the form of salary, the salary should be reachable to coinpensate the community for the interest foregone. As in the preinature retirement situation, the employee spouse will not be prejudiced so long as the allocation is made on a monthly basis, beginning at the time the pension would have inatured, under the court's continuing jurisdiction. Allocation should continue as long as the employee spouse is receiving such substitute counpensation.

Courts so far have not applied the spousal election standard to complex einployinent elections, in part on the theory that it inight infringe on the employenent relationship. But so long as the second einployment generates surplus compensation over and above what would have been the employee spouse's separate property had he remained at the first eniployinent, the application of the spousal election standard would not impair the einployment relationship. On the contrary, the method of allocation proposed in this Note would both protect the community interest and, at the saine time, preserve the employee spouse's right to inake employinent-related decisions in an environinent free from extraneous economic considerations.

\section{CONCLUSION}

In Stenquist, the California Suprene Court was faced with the difficulty of allocating pension rights that were composed of both separate 
and community property components. Although the court made some effort to look beneath the label of the pension and determine whether the "disability" pension served a retirement function, it implicitly settled upon the simple mathematical formula that pension rights will be deemed separate property only to the extent that they exceed the value of any community property rights they supplant. Thus, Stenquist not only divides vested pension rights in a reasonable and equitable manner, it also protects nonvested rights by neutralizing any incentive the employee spouse may have to impair the community interest in such rights.

The choice between alternative vested rights, one a disability pension and the other a retirement pension, is what the courts term a simple election. This was the situation im Stenquist. As this Note demonstrates, however, the logic of Stenquist need not be limited to such simple elections, but may be extended to counteract any similar incentive to defeat the community interest in more comphicated employment-related elections. This approach will provide broader protection to community pension rights.

Mark Kester Brown*

In re Marriage of Morrison. ${ }^{1}$ The court announced the guidelines to be followed by a trial court in determining whether or not to retain jurisdiction to extend a spousal support order. The court held that, following the dissolution of a lengthy marriage, jurisdiction to extend a support order should not be termmated unless the record clearly mdicates that the supported spouse will be able to meet his or her financial needs at the time selected for termination of jurisdiction.

Upon dissolution of a marriage of twenty-eight years, the trial court had ordered monthly spousal support to the wife for a period of eight years, and had retained jurisdiction to extend the order for an additional three years. At the end of that period all spousal support would terminate absolutely, althougli no showing had been made that the wife would be self-supporting at the end of eleven years.

Prior to Morrison, the courts of appeal were in conflict as to the

* A.B. 1976, Stanford University; J.D. 1979, Boalt Hall School of Law, University of California, Berkeley.

1. 20 Cal. 3d 437, 573 P.2d 41, 143 Cal. Rptr. 139 (1978) (Bird, C.J.) (unanimous decision). 
proper rule governing a trial court's retention of jurisdiction over spousal support awards. Civil Code section $4801(\mathrm{~d})^{2}$ provides for absolute termination of spousal support at the end of a period specified in the trial court's order of support payment, unless the trial court retains jurisdiction to extend the order. As interpreted by one line of cases, ${ }^{3}$ section 4801(d) permitted a trial court to terminate its jurisdiction over spousal support without any showing that the supported spouse could achieve economic independence by the time set for termination. This rule was based on the appellate courts' behef that the legislature, in enacting section 4801(d), intended to encourage termination of jurisdiction in order to reduce the number of future inodification proceedings and provide the parties with soine degree of economic stability following dissolution of their marriage. ${ }^{4}$ Another line of cases ${ }^{5}$ held that, after a lengthy marriage, jurisdiction over spousal support should be retained absent evidence of the supported spouse's future ability to achieve financial self-sufficiency.

In endorsing the latter view, the supreme court reviewed the legislative history of Civil Code section 4801(d) and concluded that the statute inerely specifies the procedures to be followed by a trial court in order to retain jurisdiction over spousal support awards. The court found that section 4801 (d) does not encourage a policy favoring terinination, rather than retention, of jurisdiction over spousal support. Indeed, as a procedural standard, the statute has no bearmg on the substantive question of the extent to which jurisdiction should be retained in a particular case. Rather, this question is to be decided by consideration of "the circuinstances of the respective parties, including the duration of the marriage, and the ability of the supported spouse to engage in gainful employment," as set forth in Civil Code section $4801(a){ }^{6}$

Ultimately, the supreme court's interpretation of section 4801(d) reflects a policy concern fundainentally different from those discussed in the rejected appellate court interpretations of the statute. In those cases, the courts placed a premium on judicial efficiency and the advantage of offering the parties a predictable economic future. The supreine court, by contrast, based its decision on the injustice that may arise when spouses who are unable to become financially independent

2. Cal. Crv. Code $\S 4801$ (d) (West Supp. 1978).

3. In re Marriage of Lopez, 38 Cal. App. 3d 93, 113 Cal. Rptr. 58 (3d Dist. 1974); In re Marriage of Patrino, 36 Cal. App. 3d 186, 111 Cal. Rptr. 367 (1st Dist. 1973). 368.

4. 38 Cal. App. 3d at 118-19, 113 Cal. Rptr. at 74; 36 Cal. App. 3d at 189, 111 Cal. Rptr. at

5. In re Marriage of Dennis, 35 Cal. App. 3d 279, 110 Cal. Rptr. 619 (2d Dist. 1973); In re Marriage of Rosan, 24 Cal. App. 3d 885, 101 Cal. Rptr. 295 (4th Dist. 1972).

6. Cal. Civ. Code $\S 4801$ (a) (West Supp. 1978). 
are arbitrarily cut off from court jurisidiction over their sole means of support. Thus, a trial court abuses its discretion when it creates the potential for such injustice. 